ONTOPOWER 


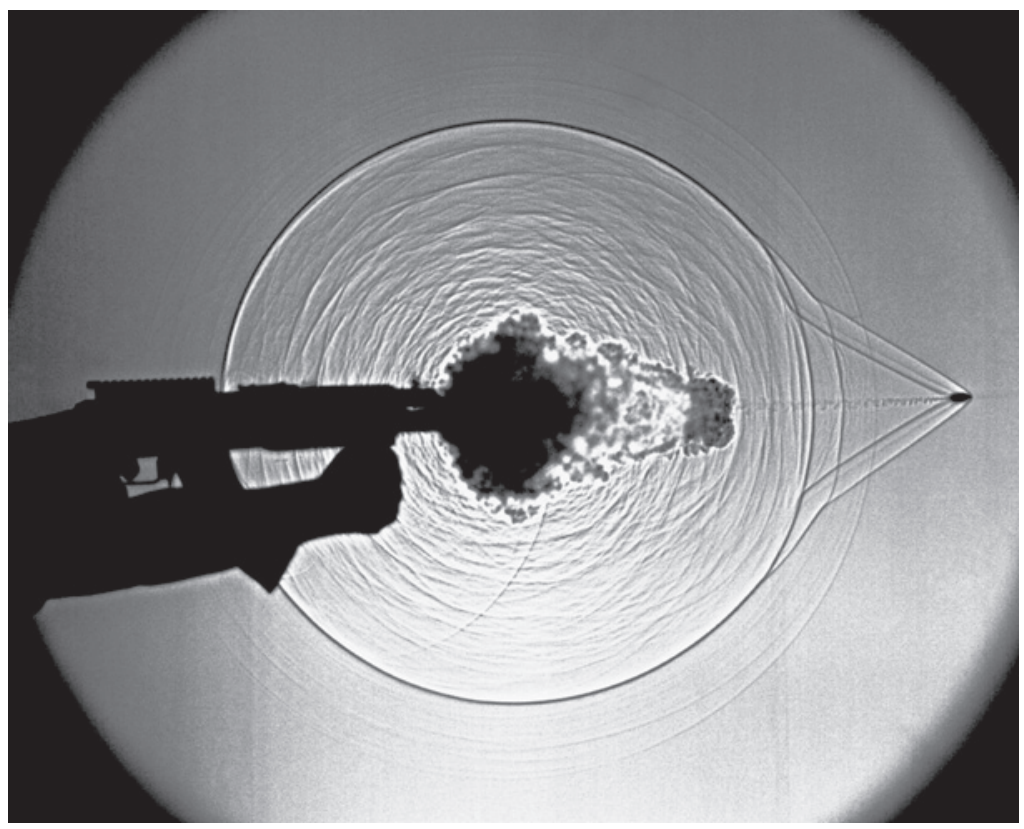




\section{BRIAN MASSUMI}

Ontopower:

War, Powers,

and the State

of Perception

DUKE UNIVERSITY PRESS DURHAM AND LONDON 2015 


\section{(C) 2015 Duke University Press}

All rights reserved

Printed in the United States of America on acid-free paper $\infty$

Designed by Natalie F. Smith

Typeset in Quadraat Pro by Westchester Book Group

Library of Congress Cataloging-in-Publication Data

Massumi, Brian, author.

Ontopower : war, powers, and the state of perception / Brian Massumi.

pages $\mathrm{cm}$

Includes bibliographical references and index.

ISBN 978-0-8223-5952-4 (hardcover : alk. paper)

ISBN 978-0-8223-5995-1 (pbk. : alk. paper)

ISBN 978-0-8223-7519-7 (e-book)

1. Power (Social sciences)-United States-History-21st century. 2. War on Terrorism, 2001-2009. 3. National security-United States-History-21st century. I. Title.

HN90.P6M37 2015

$320.01^{\prime} 1-d c 23 \quad 2015001928$

Frontispiece art: AK-47 firing, shadowgraph, Dr. Gary S. Settles/Science Photo Library.

Cover art: Erin Manning, 9/11 (2001), acrylic and mixed media, detail. Courtesy of the artist. Photo by Leslie Plumb.

The author acknowledges the generous support of the Social Science and Humanities Research Council of Canada (SSHRC). 